\title{
Research Paper Cultivation and production cost of cumin in Banaskantha district of north Gujarat
}

See end of the paper for authors' affiliations

Correspondence to : R.R. PATEL

AICRP-On Farm Research Project, S.D. Agricultural University, JAGUDAN (GUJARAT) INDIA

Email : rrpatelecon@ gmail.com

Paper History :

Received : 10.01.2017;

Revised : 01.02.2017;

Accepted : 11.02 .2017
Abstract : India produces 70 per cent of global spice production (105100 MT of total production in 2010). In Gujarat state, cumin is grown mostly in the northern district of the state i.e. Mehsana, Banaskantha and Patan district. Cumin was grown under 2,16,000 hectares in Gujarat state, out of this 39897 hectare was contributed by Banaskantha district during the year 2011-12. The aimed of this study was to analyze the cultivation/production cost of cumin and to find return over cost. The study is based on data collected from 108 farmers selected from six villages selected purposively and one regulated market i.e., Tharad of Banaskantha district of Gujarat state. It was calculated that the average total cost of cultivation of cumin was 48905/- Rs. per hectare and net income of cumin was 39852/- Rs. per hectare for the year 2012-2013. The cost of cultivation of cumin for small farmers was higher as compared to medium and large size farmers. Major inputs cost was small farmers contributed 33.09 per cent to total cost of cultivation which was 8.60,20.34 and 4.15 per cent, for seed, human labour and fertilizer, respectively. The cost of cultivation $\left(\operatorname{cost} C_{2}\right.$ ) for small size group of farmers was estimated 55592 Rs. /ha.

KeY Words : Cumin, Cost of cultivation per hectare, Cost of production per quintal, Gross return, Net return

How To Cite This Paper : Salve, P.D., Patel, R.R., Patel, R.M. and Patel, A.S. (2017). Cultivation and production cost of cumin in Banaskantha district of north Gujarat. Internat. Res. J. Agric. Eco. \& Stat., 8 (1) : 138142, DOI : 10.15740/HAS/IRJAES/8.1/138-142. 